speeches will be published in French. Advantage was taken of the character of the gathering to hold a discussion on the international and social implications of modern science, a subject dominated at the present time by atomic energy, the practical fruit of the scientific labours of Rutherford and his colleagues throughout the world.

There was a reception at the Maison de la Pensée Francaise and a lecture on "The Function of International Science in the Solution of the Economic Problems of To-day" delivered in French by Prof. J. D. Bernal.

It was particularly fitting that these celebrations should have been held in France, where Becquerel and the Curies laid the foundation of nuclear physics by their pioneering discoveries in radioactivity, and especially that the daughter and son-in-law of the Curies should have been largely responsible for the conception and organisation of the conference. Those of us who were students and colleagues of Rutherford found the proceedings in every way appropriate, magnificent in conception and strangely moving. This spontaneous tribute to the genius and lovable personality of Rutherford merits the gratitude of all Britons.

The organisation of the commemoration was in the hands of a committee of the World Federation of Scientific Workers, and its great success was due largely to the generous hospitality of the French Government and its full participation in the proceedings. The United Nations Educational, Scientific and Cultural Organisation recognized the unique significance of the occasion by providing funds to cover the travelling expenses of many who attended.

M. L. OLIPHANT

\section{CULTIVATION OF THE CRICKET BAT WILLOW}

TN Forestry Commission Bulletin No. 17 (London : 1 H.M. Stationery Office, 1946) the cultivation of the cricket bat willow is described. The tree willows are divided into two groups. In the first, the trees are pollarded and yield small produce such as stakes and poles, the latter used for hurdles and rough fencing. In the second group, timber of larger size is produced which may be used, as in some parts of the Midlands, for making field gates, but of which the best known and most important manufactured product is the cricket bat. Pollarded willows are very characteristic sights in many parts of England as, for example, in the valley of the Thames ; Somersetshire marshes ; the levels of the Bedfordshire Ouse, and along many of the small streams in southern England. In most cases the agricultural population know well how to deal with this type of tree, the numbers of which do not appear to diminish in the parts of the country where they are found, and their produce furnishes a very useful source of certain types of woody material in use by the agricultural community.

When the object is to produce material of timber size, the areas devoted to willow must be treated on a more intensive forestry method, and this applies to a very high degree in the case of trees from which it is desired to obtain timber for the manufacture of cricket bats. With this object in view the willow must be selected with very great care so far as the willow stock is concerned, and to-day, for the purpose in question, it has led to an ever-increasing demand for Salix alba var. coerulea. The demand for this variety has been a matter of gradual development, and the methods of its cultivation have been carefully improved, based on trial and error with reference to methods of propagation and planting.

In the past, a number of private owners have tried to undertake the production of this high-quality willow timber, with the object of selling it as material for cricket bat production, and considerable failures have resulted. It is not that the cultivation of the willow itself is actually difficult, but a great deal of close attention is necessary, and more especially during its early life, and the right variety must be obtained at the start. It is for this reason that the Forestry Commission has had drawn up and issued this bulletin on the cultivation of this valuable product. The subject is dealt with under situation, climate, soils, propagation (by various methods), planting and tending the trees; also the various types of possible damage are discussed; the character and uses of willow timber, and finally the systematy of the cricket bat willow and its allies. In fact, the bulletin may be considered to be an up-to-date guide to any who wish to take up this interesting branch of economic tree-growing. There is also a number of plates illustrating the text.

\section{FORTHCOMING EVENTS}

(Meeting marked with an asterisk * is open to the public)

\author{
Saturday, December 6
}

NORTH OF ENGLAND INSTITUTE OF MINING AND MECHaNicaL Mr. Donald Hindson, Jr. : "Some Aspects of Dutch Coal Mining".

\section{Monday, December 8}

CHFMICAL SOCIETY (in the Main Chemistry Lecture Theatre, The University, Edgbaston, Birmingham), at 4.30 p.m.-Dr. W. A. Waters : "Mechanisms of Oxidation".

INSTITUTION OF THE RUBBER INDUSTRY, MIDLAND SECTION (at the James Watt Memorial Institute, Great Charles Street, Birmingham), at 7.15 p.m.-Dr. D. Parkinson: "Newer Developments in Carbon Black".

\section{Tuesday, December 9}

ZoOLOGICAL SocietY of LoNDON (at Regent's Park, London, N.W.8), at 5 p.m. - Scientific Papers.

Institution OF CHEMICAL ENGINEERs (at the Geological Society, Burlington House, Piccadilly, London, W.1), at 5.30 p.m.-Mr. N. H.' Pratt: "The Heat Transfer in a Reaction Tank Cooled by Means of a Coil"

Institution of Electrical ENGINEERS, RADIo SECTION (at Savoy Place, Victoria Embankment, Iondon, W.C.2), at 5.30 p.m.-Mr. B. E. G. Mittell : "Commercial Disc Recording and Processing".

Illuminating ENeINeEring Society (at the E.T.M.A. Lighting Service Bureau, 2 Savoy Hill, London, W.C.2), at

Nolson: "Decoration and Industrial Lighting". CoUNTIES SECTION (in the Material Research Laboratory, Philips lamps, Ltd., New Road, Mitcham Junction), at 7.15 p.m.- Mr. C. G. A. Hill, assisted by colleagues: "Luminescent Materialstheir Properties and Uses", with demonstrations.

\section{Wednesday, December 10}

INSTITUTE OF FUeL, NORTH-WESTERN SECTION (at the Engineers' Club, Albert Square, Manchester), at 2 p.m.-Mr. S. W. Bertenshaw : "Oil Firing Practice,".

ROYAL Society oF ARTS (at John Adam Street, Adelphi, London, W.C.2), at 2.30 p.m.-Mr. Michael Graham: "Science and the Fishing Industry".

GEoLogical SoctwTy (at Burlington House, Piccadilly, London, W.1), at 5 p.m. - Scientific Papers.

Institution of ELECTRICAL ENGINEERS, Transmission SeCtion INSTITUTION OF ELECTRICAL ENGINEERS, TRANSMISSION SECTION
(at Savoy Place, Victoria Embankment, London, W.C.2), at 5.30 p.m. Mr. H. Hurworth : "Some Observations on Oil Deterioration in Transformers and Switchgear"'; Mr.

MANCHESTER LITERARY AND PHILOSOPHICAL SOCIETY, SOCIAT Philosophy SkCtion (at the Portico Library, 57 Mosley Street, Manchester), at 5.30 p.m.-Lecture by Miss C. V. Wedgwood."

SOCIETY OF CHFMIOAL INDUSTRY, NUTRIMION PANEL of the FOOD Group (at the Chemical Society, Burlington House, Piccadilly, London, W.1), at 6 p.m.- "Organoleptic Tests in the Food Industry". 